\title{
Efikasi Kinin-Doksisiklin pada Pengobatan Malaria Falsiparum Tanpa Komplikasi
}

\author{
Fitri Arianty Lubis, Syahril Pasaribu, Chairuddin P. Lubis \\ Departemen Ilmu Kesehatan Anak FK-USU / RSUP H. Adam Malik Medan
}

\begin{abstract}
Pengobatan malaria masih merupakan masalah yang sering dihadapi karena terjadinya resistensi terhadap beberapa obat anti malaria. Kombinasi dua macam obat saat ini yang sering dipergunakan, terutama pada daerah hiperendemis, untuk meningkatkan efikasi dari obat tersebut. Kombinasi kinin-doksisiklin adalah salah satu kombinasi obat anti malaria yang dapat diberikan sebagai terapi alternatif untuk pengobatan malaria falsiparum tanpa komplikasi. Pada beberapa penelitian ditunjukkan bahwa kombinasi kedua obat ini mempunyai efikasi yang baik. (Sari Pediatri 2008;10(4):246-9).
\end{abstract}

Kata kunci: artesunat-amodiakuin, kinin-doksisiklin, malaria falsiparum tanpa komplikasi

M alaria merupakan masalah kesehatan pada beberapa daerah di Indonesia, terutama di bagian timur yaitu Sulawesi, Maluku, dan beberapa daerah di luar Jawa. ${ }^{1}$ Berbagai upaya pemberantasan malaria telah dilakukan, namun prevalensi malaria masih tetap tinggi. Hal ini disebabkan adanya berbagai hambatan dalam pemberantasan malaria, diantaranya resistensi vektor terhadap insektisida dan resistensi parasit terhadap obat anti malaria. Resistensi parasit malaria terhadap klorokuin muncul pertama kali di Thailand pada tahun 1961 dan Amerika Serikat pada tahun

\footnotetext{
Alamat Korespondensi:

dr. Fitri Arianty Lubis Departemen Ilmu Kesehatan Anak Fakultas Kedokteran Universitas Sumatera Utara / RSUP H. Adam Malik Medan Jl. Bunga Lau No 17 Medan. Tel. (061) 8361721-8365663. Fax (061) 8361721 E-mail: bikeafkusu@telkom.net ; kotak pos 697 Medan 20136
}

1962. Di Indonesia resistensi Plasmodium falsiparum terhadap klorokuin pertama kali dilaporkan di Samarinda pada tahun 1974, kemudian menyebar dan pada tahun 1996 kasus malaria yang resistensi klorokuin sudah ditemukan di seluruh propinsi di Indonesia. ${ }^{2}$

Malaria merupakan penyakit endemis atau hiperendemis di daerah tropis maupun subtropis dan menyerang negara dengan penduduk padat. Diperkirakan prevalensi malaria di seluruh dunia berkisar antara 160-400 juta kasus. ${ }^{3}$ Malaria berasal dari kata mala artinya buruk dan aria atau air artinya udara, dikatakan udara buruk karena tingginya prevalensi malaria di seluruh dunia pada daerah tropis berair payau. Prevalensi juga tinggi di daerah yang hangat dan basah. ${ }^{4}$ Dijumpai 140 spesies plasmodium, tetapi hanya 4 spesies yang dikenal menginfeksi manusia yaitu Plasmodium falsiparum, vivax, ovale, dan malariae dengan transmisi melalui nyamuk Anopheles. Spesies yang paling banyak ditemukan adalah Plasmodium 
falsiparum dan Plasmodium vivax. Infeksi yang disebabkan Plasmodium falsiparum adalah infeksi yang paling besar menunjukkan angka kesakitan dan kematian. ${ }^{5,6}$ Pada tahun 2002, 1.337 kasus malaria dilaporkan di Amerika Serikat dan Plasmodium falsiparum merupakan kasus terbanyak (50\%) dan sering menjadi malaria berat. ${ }^{7}$ Malaria adalah penyakit infeksi yang paling sulit dalam pengobatan dibandingkan penyakit infeksi yang lain. ${ }^{8}$ Masa inkubasi dapat berlangsung 6-40 hari. Gejala dapat muncul setelah satu bulan kemudian, walaupun telah mendapat profilaksis. ${ }^{?}$

Gambaran klinis terdiri dari 3 stadium yaitu ${ }^{3}$ stadium dingin, stadium demam, dan stadium berkeringat.

Cara penularan ${ }^{3,10}$

- Penularan secara alamiah, melalui gigitan nyamuk Anopheles

- Penularan tidak alamiah dapat terjadi secara, - Malaria bawaan (kongenital)

- Secara mekanik, melalui transfusi darah atau melalui jarum suntik

- Secara oral, cara penularan ini pernah dibuktikan pada burung, ayam, dan monyet.

Diagnosis ditegakkan berdasarkan pemeriksaan hapusan darah tebal dan tipis pasien ditemukan Plasmodium falsiparum pada. Obat anti malaria ideal sebaiknya murah dan mempunyai efikasi yang baik dengan lama pengobatan singkat. ${ }^{11}$ Alecrim dkk $^{12}$ melaporkan bahwa kombinasi kinin-dosisiklin dapat menurunkan angka Plasmodium falsiparum setelah tujuh hari pengobatan. Penelitian Newton $\mathrm{dkk}^{13}$ mengatakan bahwa doksisiklin oral ditambah dengan obat lain (kinin atau golongan artemisin) diperlukan dalam menurunkan parasitemia untuk pengobatan malaria falsiparum.

\section{Kinin}

Kinin adalah alkaloid dari kulit pohon sinkona. ${ }^{14}$ Dosis yang dipakai pada anak adalah $5-10 \mathrm{mg} / \mathrm{kgbb} /$ dibagi 3 dosis diberikan selama 7 hari. ${ }^{3}$ Kinin adalah alkaloid terbaik, sangat cepat diabsorbsi, nilai puncak plasma dapat tercapai setelah 1 sampai 3 jam, dan secara luas didistribusikan ke jaringan. ${ }^{14}$ Kinin mempunyai eliminasi waktu paruh 7-12 jam pada keadaan normal, tetapi pada kasus malaria waktu paruh adalah 8-21 jam. Delapan puluh persen kinin dimetabolisme di hati dan sebagian besar diekskresi melalui air seni. ${ }^{15}$ Setelah kinin melewati lambung tanpa mengalami perubahan, dengan cepat dan sempurna diserap di usus halus, kemudian sebagian besar (70\%) beredar dalam bentuk basa yang terikat dalam protein plasma. Mekanisme kerja kinin dapat membentuk ikatan hidrogen dengan DNA yang akan menghambat sintesis protein sehingga pembelahan DNA dan perubahannya menjadi RNA akan tercegah. Selain itu, kinin dapat menekan beberapa sistem enzim sehingga digolongkan racun protoplasma yang bersifat umum.,16

Kinin bersifat toksik terhadap berbagai bakteri dan organisme bersel tunggal seperti tripanosoma, plasmodium dan spermatozoa, serta mempunyai daya iritasi kuat. Bila diberikan secara oral dapat menyebabkan nyeri di lambung, mual, dan muntah. Dosis terapi menunjukkan dampak terhadap susunan saraf pusat berupa analgesik dan antipiretik. Penurunan demam pada pasien malaria, membuat kinin digunakan sebagai terapi simtomatik demam. Padahal penurunan demam pada pasien malaria terutama disebabkan oleh dampak langsung terhadap plasmodium dan bukan karena daya antipiretik. ${ }^{17}$ Kinin bersifat skizontosid dan gametosit, terutama gametosit intra-eritrosit. Pengobatan kinin oral diberikan untuk mengobati malaria tanpa komplikasi dan bila resisten terhadap klorokuin pada malaria falsiparum. Kinin aman diberikan pada wanita hamil dan anak-anak. Efek samping yang sering tampak adalah telinga berdenging, tuli, nyeri kepala, mual, dan gangguan penglihatan. ${ }^{3,7}$ Monoterapi kinin oral pada anak dapat menyebabkan komplikasi karena dalam 7 hari pengobatan mudah terjadi efek samping, pada sekitar $70 \%$ pasien. ${ }^{18}$

\section{Doksisiklin}

Dosis doksisiklin pada anak yang menderita malaria adalah $1,5-2 \mathrm{mg} / \mathrm{kgBB} / \mathrm{hari}$, diberikan selama 7 hari. ${ }^{4}$ Doksisiklin adalah turunan tetrasiklin yang mempunyai absorbsi paling besar yaitu 95\%$100 \%$. Absobsi terjadi di usus kecil bagian atas dan absorbsi tidak terganggu dengan adanya makanan. ${ }^{19}$ Doksisiklin mempunyai waktu paruh yang panjang yaitu antara 16 -18 jam, diabsorbsi secara sempurna dan diekskresikan perlahan dengan pemberian dosis satu kali perhari. ${ }^{20}$ Absorbsi yang sangat baik 
dengan konsentrasi serum puncak antara 3-4 mcg/ $\mathrm{ml}$ selama 2 jam dengan $200 \mathrm{mg}$ dosis oral. Sekitar 80\%-95\% doksisiklin berikatan dengan protein, dan 90\% diekskresi melalui feses dan sebagian lagi melalui filtrasi glomerulus ginjal.,, 21

Doksisiklin adalah obat berspektrum luas dan berdampak menghambat protein. Bersifat bakteriostatik pada bakteri Gram positif dan negatif, termasuk anaerob, rickettsiae, chlamydiae, mycoplama, dan aktif melawan protozoa misalnya amoeba. ${ }^{15}$ Sejak harga doksisiklin dan tetrasiklin hampir sama, pemberian doksisiklin satu kali dalam sehari lebih menguntungkan daripada pemberian tetrasiklin empat kali dalam sehari. ${ }^{17,22}$

Efek samping yang dapat terjadi setelah pemberian doksisiklin adalah mual, diare, bercak merah, fotosensitivitas, kerusakan pada gigi dan gangguan pertumbuhan tulang. ${ }^{4}$ Fotosensitivitas dapat disebabkan oleh golongan tetrasiklin yang manapun, tetapi paling sering tampak pada pemberian doksisiklin. ${ }^{8}$ Doksisiklin sebaiknya tidak diberikan pada wanita hamil dan anak usia di bawah usia 8 tahun karena dapat mempengaruhi pertumbuhan tulang dan gigi pada anak. ${ }^{23}$ Dampak yang paling sering muncul pada anak adalah pengaruh perubahan warna pada gigi dan tulang. Hal ini dapat terjadi karena mekanisme gangguan pada tempat penyimpanan kalsium. Warna pada gigi menetap dan muncul sebagai hypoplasia enamel. Gangguan pertumbuhan pada tulang secara luas telah diketahui jika ibu mengkonsumsi tetrasiklin pada saat hamil atau tetrasiklin diberikan pada masa neonatal. ${ }^{24,25}$

Pada salah satu penelitian di sekolah disebutkan bahwa pemberian tetrasiklin dan turunannya mempengaruhi penyerapan kalsium. Dampak yang paling sering terjadi pada anak di beberapa kelas sehingga disebutkan bahwa tetrasiklin dan turunannya sebagai kontraindikasi pada anak usia di bawah 8 tahun sejak tahun 1970-an. Namun pada beberapa kasus apabila tetrasiklin masih diindikasikan, doksisiklin merupakan pilihan karena lebih sedikit mengikat kalsium dan menghasilkan efek samping minimal dibandingkan golongan tetrasiklin yang lain., ${ }^{4,26}$

Seperti tetrasiklin, ulkus pada esophagus dapat dicegah dengan banyak minum air. Gejala gastrointestinal yang lain dapat dikurangi dengan makanan saat memakai obat. Susu sebaiknya dihindari karena dapat mengurangi absorbsi obat. ${ }^{17}$ Sebaiknya doksisiklin oral diberikan dengan air atau juice. Antasid, susu jenis apapun, dan suplementasi zat besi sebaiknya diberikan 1 jam sebelum atau 2 jam setelah memakan doksisiklin. ${ }^{4}$

\section{Kinin-Doksisiklin}

Doksisiklin sebaiknya tidak diberikan dengan dosis tunggal untuk pengobatan malaria karena cara kerja lama. Doksisiklin sama halnya dengan tetrasiklin, dapat digunakan kombinasi dengan kinin untuk mengurangi efek samping kinin jika dibandingkan dengan dosis tunggal. ${ }^{17}$

Salah satu penelitian di Brazil yang membandingkan antara artemeter-lumefantrin dengan kinindoksisiklin mendapatkan pada kelompok yang mendapat artemeter setelah hari ketiga, parasit berkurang hingga mencapai nol, sedangkan pada kelompok kinin-doksisiklin parasit berkurang 48,8\%. Temuan tersebut menunjukkan bahwa derivat artemisin memberikan efikasi yang baik, tetapi bila obat ini tidak tersedia maka kinin-doksisiklin masih tetap dapat digunakan sebagai pilihan lain dalam pengobatan malaria falsiparum di daerah resistensi tinggi. ${ }^{18,21}$

Penelitian di Gabon membuktikan bahwa pemberian kinin kombinasi dengan klindamisin atau doksisiklin memberikan efikasi yang lebih baik dibandingkan pemberian kinin dosis tunggal pada pengobatan Plasmodium falsiparum di daerah hiperendemis. Pada kelompok yang mendapat kinin dosis tunggal memberi kesembuhan 38\% sedangkan kelompok yang mendapat kombinasi kinin-klindamisin atau kinin-doksisiklin mendapat kesembuhan $90 \%{ }^{19}$

\section{Ringkasan}

Resistensi pada pengobatan malaria falsiparum masih menjadi masalah di seluruh dunia. Penggunaan klorokuin, atau sulfadoksin pirimetamin dan obat malaria yang lain telah menimbulkan resistensi. World Health Organization merekomendasikan penggunaan kombinasi artemisin sebagai pilihan pertama saat ini, tetapi jika obat tidak tersedia dan karena harga yang mahal maka diperlukan obat lain. Kinindoksisiklin adalah kombinasi obat malaria falsiparum tanpa komplikasi yang dapat diberikan sebagai alternatif. Selain harganya yang murah, efikasinya telah dibuktikaan pada beberapa penelitian. 


\section{Daftar Pustaka}

1. Harianto PN. Manifestasi klinik, komplikasi, dan diagnosis malaria. Jakarta: Medika; 1993.h.31-8.

2. Tarigan J. Kombinasi kina tetrasiklin pada pengobatan malaria falsiparum tanpa komplikasi di daerah resisten multidrug malaria. Medan: Bagian Ilmu Penyakit Dalam FKUSU; 2003.h.1-20.

3. Malaria. Dalam: Soedarmo SSP, Garna H, Hadinegoro SRS, penyunting. Buku ajar ilmu kesehatan anak. Edisi ke-1. Jakarta: IDAI; 2005.h.442-69

4. Pediatric parasitosis. Dalam: Gupte $S$, penyunting. The short textbook of pediatrics. Edisi ke-9. New Delhi: Jaypee Brothers; 1998.h.204-19.

5. Philip SR. Current status of malaria and potential for control. Clin Microbiol Rev 2001;14:208-26.

6. Stauffer W, Fischer PR. Diagnosis and treatment of malaria in children. Clin. Inf. Dis 2003;37:1340-8.

7. Ghazanchyan. Malaria treatment. Diunduh dari: URL: http://www.malaria.am

8. Krause PJ. Malaria (plasmodium). Dalam: Behrman RE, Kliegman RM, Jenson HB, penyunting. Nelson textbook of pediatrics. Edisi ke-16. Philadelphia: WB Saunders; 2003.h.1049-2100.

9. Habel A, penyunting. Selected infections with concerns specific to children. Dalam: Synopsis of paediatrics. Oxford: Butterworth Heinemann; 1993.h.610-30.

10. Siregar M. Epidemiologi malaria. Simposium recent advances on malaria. Medan: Bagian Patologi Klinik FK USU; 1994.h.1-12.

11. Silachamroon U, Krudsood S, Phophak N, Looareesuwan S. Management of malaria in Thailand. Korean J Parasit 2002;40:1-7.

12. Alecrim MG, Lacerda MV, Mourao MP, Alecrim WD, Padilha A, Cardoso BS, Boulos M.. Successful treatment of plasmodium falsiparum malaria with a six dose regimen of artemether lumefantrine versus quinine doxycycline in the western amazon region of Brazil. Am J Trop Med 2006;74:20-5.

13. Newton NP, Chaulet FJ, Brockman A. Pharmacokonetics of oral doxycycline during combination treatment of severe falciparum malaria. Antimicrob Agents and Chemother 2005;4:1622-5.

14. Sukarban S, Zunilda SB. Obat malaria. Dalam: Ganiswara SG, Setiabudy R, Suyatna FD, Purwantyastuti, penyunting. Farmakologi dan terapi. Edisi ke-4. Jakarta:FKUI; 1995.h.545-59.

15. Chambers HF. Chloramphenicol, tetracycline, macrolides, clindamycin, \& streptogramins. Dalam: Katzung BG, penyunting. Basic \& clinical pharmacology. Edisi ke-7. America: Appleton \& Lange; 1998.h.743851.

16. Rudolph AM, penyunting. Antibiotics that inhibit protein synthesis. Dalam: Pediatrics. Edisi ke-8. California: Appleton \& Lange; 1987.h.465-684.

17. Handler P. Sulfonamides and antibiotics. Dalam: Gerald MC, penyunting. Pharmacology an introduction to drugs. Edisi ke-2. America: Prentice Hall; 1981.h.55773.

18. The use of antimalarial drugs. Pharmacotherapy Mei 2007;16:1-5 Didapat dari www.rollbackmalaria.org/ cmc_upload/0/000/014/923/am_toc.htm

19. Buck ML.Pediatric pharmacotherapy a monthly newsletter for health care professionals from the children's medical center at the university of virginia. Doxycycline for pediatric infections. Pharmacotherapy 2003;9:312-25.

20. Metzger W, Mordmuller B, Graninger W, Bienzle U, Kremsner P. High efficacy of short term quinine antibiotic combinations for treating adult malaria is hyperendemic. Antimicrob Agents and Chemother. 1995;39:245-6.

21. Ghai OP, penyunting. Common protozoal and helminthic infections. Dalam: Essential pediatrics. Edisi ke-5. New Delhi: Mehta; 2001.h.213-8.

22. Oemijati S. Masalah malaria di Indonesia. Jakarta: FKUI; 1990.h.1-23.

23. Weinerg A, Levin MJ. Infections: parasitic \& mycotic. Dalam: Hay WW, Hayward AR, Levin MJ, Sondheimer JM, penyunting. Current pediatric diagnosis \& treatment. Edisi ke-16. North America: McGraw Hill; 2003.h.1213-21.

24. Jolly $H$, Levene MI, penyunting. Diseases due to parasites. Dalam: Disease of children. Edisi ke-5. Oxford: Blackwell; 1988.h.299-395.

25. Rosenthal PJ. Antiprotozoal drugs. Dalam: Katzung BG, penyunting. Basic and clinic pharmacology. Toronto: MC Graw Hill; 2004.h.864-84.

26. Meeks, Rowland M, Connoly M. Outline strategy for malaria control in complex emergencies. Geneva: WHO; 1998.h.4-20. 